\title{
The Relationship of Writing Apprehension Level and Self-efficacy Beliefs on Writing Proficiency Level among Pre-university Students
}

\author{
Termit Kaur Ranjit Singh ${ }^{1} \&$ Saravana Kumar Rajalingam ${ }^{1}$ \\ ${ }^{1}$ School of Educational Studies, Universiti Sains Malaysia \\ Correspondence: Termit Kaur Ranjit Singh, School of Educational Studies, Universiti Sains Malaysia, 11800 \\ Minden, Pulau Pinang, Malaysia. Tel: 604-653-3760. E-mail: termitk@usm.my
}

Received: April 25, 2012 Accepted: June 14, 2012 Online Published: July 1, 2012

doi:10.5539/elt.v5n7p42 URL: http://dx.doi.org/10.5539/elt.v5n7p42

\begin{abstract}
The purpose of this study was to determine the level of writing apprehension and how writing apprehension level and writing self-efficacy beliefs influences writing proficiency level among pre-university students. Participants were 320 pre-university students from a northern region college offering this programme. All the respondents were administered with three instruments measuring their writing apprehension levels and writing self-efficacy beliefs and their writing proficiency. The writing apprehension levels among these respondents were found to be average. Self-efficacy factors revealed an inverse relationship with writing apprehension level. The relationship between writing apprehension level and writing proficiency indicated that the higher the apprehension level the better the respondents performance. Students' views with regard to their writing apprehension level are also presented. These findings are supported in the literature and discussions. Based on the findings, the study presents some recommendations to overcome this problem.
\end{abstract}

Keywords: self-efficacy beliefs, apprehension level, writing proficiency, pre-university students

\section{Introduction}

Lately, the general scenario of the Malaysian Education System has put on the emphasis of English language as the medium of instruction to impart knowledge via lesson plans starting from pre-university level to tertiary education in the universities. However, Azlina (2006), pointed out that the reality for a large number of Malaysian students is that English language is not the medium of choice to function socially and rarely use English language to discuss the contents of their school subjects.

Since, English language has been given the priority as a medium of imparting knowledge at the university level, so, an emphasis is has been made on the use of English language at higher secondary or pre-university level. With the current reality pointed by Azlina (2006), indirectly it leads to writing in English language as a challenging activity for learners of English as second or foreign language.

\subsection{Background of Study}

Anxiety or apprehension which belong to the affective variables category, has inspired particular interest in the field of language acquisition and learning over the last several decades (Atay \& Kurt, 2006). The term writing apprehension was introduced by Daly and Miller (1975), however the latest definition of writing apprehension could be traced to Lee \& Krashen (2002), whom referred writing apprehension as anxiety about writing. Hence, writing apprehension could be used as a significant predictor to determine the success rate of acquiring English language proficiency among ESL learners, Carlo Magno (2008). Researchers of ESL and EFL, have proven that writing apprehension or anxiety has positive correlation on writing performance and quality (Hassan, 2001). Hanna (2010), found that highly apprehensive writers yielded low quality papers as their output, avoided writing assignment and even procrastinated compared to those students who with low apprehensive feelings. The study also showed that writing apprehension has influence at all levels even after the students have graduated from their courses.

Generally, many researchers agree that the ability to write competently is a non-inherited skill. Omaggio Hadley (1993) opined that, writing should be seen as a continuum of tasks ranging from mechanical aspects to more sophisticated actions of composition writing in the final stage. This implied that writing skills should be practiced and mastered via experiences starting from composing, telling, re-telling and transforming information into extended writing such as in expository or argumentative writing.

Furthermore, Deane (2011) also opined that writing skill does not stand on its own. It has connections with literacy 
skills, critical thinking skills and requires the writers to handle complicated challenges related to rhetorical, conceptual and linguistics. Supporting this opinion in Malaysian context, Nor Shidrah, Nuraihan \& Noor Lide (2006) also stated that, writing is a challenging activity particularly for learners of a second or foreign language and nevertheless it is an ability that they have to master in order to excel in content courses particularly at the tertiary education level. Hence, taking all these into consideration, writing activity may cause anxiety or apprehension feelings in many ESL learners.

In addition, writing apprehension has relationship with writing self-efficacy beliefs. Latif (2007), mentioned that there a vast array of studies which has shown correlations between writing apprehension and writing self-efficacy beliefs. Studies by Cheng (2002) and Rankin-Brown (2006) also supported the relationship between these two variables.

As a summary, the researchers believe that writing apprehension is a critical affect problem which is being faced by the majority of ESL students. Furthermore, writing apprehension problems if left uncheck may lead to poor proficiency in speaking, writing and also other aspects of language use.

\subsection{Problem Statement}

Writing skills are important components in the curriculum of primary, secondary, colleges and also applies for colleges offering pre-university programmes. English language syllabus for pre-university programme colleges considers writing skills as vital skills for students' needs. The aim of the syllabus specification for English language in this programme level is to develop competent users of the language who can function effectively and efficiently in social and academic contexts. Furthermore, the students enrolling for pre-university programmes are required to sit for Malaysian University English Test examination (MUET) as one of the important requirements for universities' entrance qualifications. In MUET exams, the students are tested on their writing skills in writing component whereby they are expected to write one extended writing and one focused report writing.

In a study done by Noraina Ishak (2005), it was noted that pre-university students are generally weak in four areas of language learning, i.e speaking, listening, writing and reading. Furthermore, Shaharizam, Ismail, Syahfarin Syah \& Rizal (2005) in a perception study, stated that, there were pre-university students who experienced very frustration and dissatisfaction of not being able to write effortlessly. As a result, these students felt de-motivated and viewed writing as complicated and fruitless activity. When the problem is not handled effectively by the pre-university teachers, the students will remain incompetent in writing skills and this will definitely affect their chances to perform excellently in universities in the future. Thus, it is very important for the researcher to measure and classify their apprehension and self-efficacy beliefs levels to create a friendly and less threatening feeling, for the writing activities in order to minimize the students' apprehension levels.

\subsection{Purpose of Research}

Since the ability to acquire writing skills for English language is one of the main objectives for the pre-university programmes, the purpose of this study was aimed to explore the level of writing apprehension and self-efficacy beliefs influencing the writing apprehension level among students of these pre-university students.

\subsection{Research Objectives}

The main objectives of this study were:

1. To determine the level of writing apprehension among pre-university students.

2. To determine whether self-efficacy factor is related to the level of writing apprehension among pre-university students.

3. To determine whether writing proficiency factor is related to the level of writing apprehension.

4. To find out the views of pre-university students with regard to their writing apprehension level.

\subsection{Research Questions}

The general aim of this study was to meet the objectives of the study by formulating and examining the following research questions:

i) What is the level of writing apprehension among pre-university students?

ii) Does self-efficacy beliefs factor influence the level of writing apprehension among pre-university students?

iii) Does writing apprehension level influence the writing proficiency results among pre-university students?

iv) What are the students' views regarding their writing apprehension level? 


\section{Methodology}

The general aim of this study was to find out the relationship of writing apprehension level with writing proficiency and self-efficacy belief on writing apprehension level among pre-university students.

\subsection{Population and Sample}

The population of this particular college offering the pre-university programme was 2,100 students. All students were 18 years old at the point where this study was conducted. The majority of the students were from Malay community with some Chinese and Indians. So, for the sample of this study, 320 students from the population of 2100 students were selected randomly. The reason for selecting only 320 respondents from the 2100 population was as recommended by Krejcie \& Morgan (1970). They were made up of almost equal number of males and females from this programme. The decision to select them as the sample was because they were seen as those who prefer not to write or avoid writing whenever possible.

For the instrument to solicit the respondents view on their writing apprehension level, the students were asked to answer open-ended questionnaire. The instrument consisted of 6 open-ended questions which were categorized into stress-apprehensive questions, evaluation-apprehensive questions and product-apprehensive questions (2 questions for each category). The respondents who were selected to answer the questionnaire were selected using a cutting score formula used in a previous study by Hassan (2001). The respondents with low apprehension level and high apprehension were identified as those with scores on the EWAS scale, fell a half standard deviation below and above the mean respectively, while, those who were with in the mean range were considered as average apprehensive respondents.

Basically the questionnaire consists of four parts:

\section{Part A: Students' Demographic Information}

Students' demographic information included items like age, gender, practicum, education level and race. The purpose of this information was to provide some background information about the sample respondents.

\section{Part B: Adapted Daly-Miller Writing Apprehension Test (EWAS)}

For the research purpose, the writing apprehension testing instrument, was adopted and adapted from Muhammad Abdel Latif's (2007) study. A 12-item scale was used to measure the respondents' writing apprehension level. The items of this scale were selected and adapted from three different measures. The instrument was found to be consistent with the adopted definition of writing apprehension. The test instruments were adapted from, Gungle \& Taylor's (1989) ESL version of the Daly-Miller WAT, Cheng's (2004) Second Language Writing Anxiety Inventory (SLWAI) for avoidance behaviour subscale and Graham et al.'s (1993) Attitudes toward Writing Scale. So, five point Likert scale: (1) strongly agree, (2) agree, (3) uncertain, (4) disagree, and (5) strongly disagree, was adopted for the synthesized scale. Scores on the scale range from 12 (the minimum score) to 60 (the maximum score). Due to items 3, 4, 5, 6 and 8 are negatively phrased, they were scored reversely.

\section{Part C: Adapted Shell Writing Self-Efficacy Test (SWST)}

For self-efficacy beliefs testing instrument, it was also adopted and adapted from Muhammad Abdel Latif, (2007) study. A two-part 18-item scale was used for measuring the respondents' writing self-efficacy. Part one of the scale measured respondents' confidence and judgement of their general writing ability in 8-items. The items for this part were adopted from Gungle and Taylor's (1989) ESL version of the Daly-Miller (DMAT), and Graham et al.'s (1993) Writing Self-Efficacy Scale. Part two of the scale has 10 items that measure the respondents' confidence in the possession of specific writing skills (mechanical, usage, grammar, and composition skills). Eight items of part two of the scale were adopted from Shell et al.'s (1989) Writing Self-efficacy Scale (writing component skill subscale), one item was adopted from Pajares and Valiante's (1999) Writing Skills Self-efficacy Scale, and another item was developed by Muhammad Abdel Latif, (2007).

For part two, a five point Likert scale: (1) very unconfident, (2) unconfident, (3) neither confident nor unconfident, (4) confident and (5) very confident, was used. Scores on the scale range from 18 (the minimal score) to 90 (the maximal score). Because items 1, 3, 4, and 7 in part one of the scale are negatively worded, they were reverse scored.

\section{Part D: Malaysian University English Test (MUET)}

Malaysian University English Test (MUET) was launched in 1999 and administered by Malaysian Examinations Council (Majlis Peperiksaan Malaysia). It is a test to measure candidates' English language proficiency. MUET is a compulsory examination for students who intended to further their tertiary education in Malaysian public universities. For this study, the writing component of the test is used to assess the students' performance and its 
relationship to writing apprehension. This exam is highly valid and reliable because it is a Malaysia pre-university national level examination.

\section{Part E: Semi-structured Open-ended Questions}

The semi-structured open-ended questionnaire contained only 6 questions. All the questions were adapted from the Daly-Miller Apprehension Test. These questions were classified into 3 categories which were 2 stress apprehension questionnaires, 2 evaluation apprehension questionnaires and 2 product apprehension questionnaires.

\subsection{Pilot Study}

According to (Gay, Mills \& Airasian, 2009), the pilot study is a small-scale tryout of a study conducted prior to the full-scale study to identify problems with the research plan. The pilot study can serve as a pre-test for certain study instruments (Baker, 1992). When the pilot study was conducted; the researcher randomly selected 30 respondents from the same sample to answer the instruments. The instruction and the questionnaire item were read out by the researcher to the respondents to clear their doubts and they were allocated 60 minutes to answer it. After the pilot study was carried out to determine the reliability of the questionnaire, the EWAS showed the Cronbach Alpha reliability coefficient of 0.698 and the SWST reliability coefficient was 0.773 for Part One and 0.817 for Part Two. It can be concluded that, the values for reliability coefficient fulfilled coefficient value $r>0.06$ (Cates, 1990) for producing consistent results for each time the measurement was done. Thus, the internal consistency of the instrument used was acceptable.

\section{Results}

The results were based on the responses given by the sample in the questionnaire. The data was analyzed and interpreted using statistical software in order to provide answers for the research questions. All the answers provided by the respondents were based on their personal opinions about their level of writing apprehension and self-efficacy beliefs in writing using English language.

Table 1. Respondent Profile

\begin{tabular}{lllll}
\hline Gender & & Frequency & Percent & Valid Percent \\
\hline Valid & Male & 132 & 39.3 & 41.2 \\
& Female & 188 & 56.0 & 58.8 \\
\hline \multicolumn{2}{c}{ Total } & 320 & 100.0 & 100.0 \\
\hline
\end{tabular}

The sample consisted of 320 students from this college who enrolled in the 2010/2011 session. While the portion of males and females, it consisted of 188 female and 132 male students (as shown in Table 1).

Research Question 1: What is the level of writing apprehension among these students?

Table 2. Apprehension Level

\begin{tabular}{|c|c|c|}
\hline Apprehension & No. Students & Percentage \\
\hline High Apprehension & 60 & $18.75 \%$ \\
\hline Average Apprehension & 215 & $67.19 \%$ \\
\hline Low Apprehension & 45 & $14.06 \%$ \\
\hline Total & 320 & $100 \%$ \\
\hline
\end{tabular}

The results from the statistical analysis showed that the EWAS had a mean of 36.02 and a standard deviation of 8.890. Based on the respondents' scores on the adapted EWAS instrument, the students were grouped into three apprehension levels. One or more standard deviations below the mean were judged to be high-apprehensive i.e., equal to or smaller than $24(14.06 \%)$; those whose mean scores were one or more standard deviations above the means were judged to be low-apprehensive i.e., equal to or higher than $48(18.75 \%)$. The remaining respondents were judged to have average writing apprehension level (67.19\%).

So, it can be concluded that, the writing apprehension level of the sample respondents in this college was relatively average. This implied that, majority of these respondents were not apprehensive in writing compositions or essays using English language. 
Research Question 2: Does self-efficacy beliefs factor influence the level of writing apprehension among these students?

Table 3. Correlations

\begin{tabular}{llll}
\hline & & $\begin{array}{l}\text { Writing } \\
\text { apprehension }\end{array}$ & $\begin{array}{l}\text { Self efficacy } \\
\text { beliefs }\end{array}$ \\
\hline Writing apprehension & Pearson Correlation & 1 & $-.544(* *)$ \\
& Sig. (2-tailed) & & .000 \\
& $\mathrm{~N}$ & 320 & 320 \\
Self efficacy beliefs & Pearson Correlation & $-.544(* *)$ & 1 \\
& Sig. (2-tailed) & .000 & \\
& $\mathrm{~N}$ & 320 & 320 \\
\hline
\end{tabular}

** Correlation is significant at the 0.01 level (2-tailed).

The produced output Table 3 showed the Pearson Correlation coefficient value of, $r=-0.544$ and $\mathrm{p}=0.000$ which is smaller than the significant level $0.01(p<0.01)$. Referring to the correlation coefficient Table 3 , the value $r$ was negative, so, it can be concluded that there was a significant moderate level inverse relationship between writing apprehension and self-efficacy beliefs. This implied that, the higher the level of writing apprehension, the lower self-efficacy beliefs would be. Therefore, null hypothesis was rejected.

Research Question 3: Does writing apprehension level influence the writing proficiency results?

Table 4. Correlations

\begin{tabular}{llll}
\hline & & Writing apprehension & MUET writing proficiency \\
\hline Writing & Pearson Correlation & 1 & $.184^{* *}$ \\
apprehension & Sig. (2-tailed) & .001 \\
& $\mathrm{~N}$ & 320 & 320 \\
\hline MUET & Pearson Correlation $.184^{* *}$ & 1 \\
writing & Sig. (2-tailed) & .001 & \\
proficiency & $\mathrm{N}$ & 320 & 320 \\
\hline
\end{tabular}

**. Correlation is significant at the 0.01 level (2-tailed).

The produced output Table 4 showed the Pearson Correlation coefficient value of, $\mathrm{r}=0.184$ and $\mathrm{p}=0.001$ which is smaller than the significant level $0.01(\mathrm{p}<0.01)$. So, it can be concluded that, there is a significant relationship between writing proficiency and the level of writing apprehension. This implied that, the higher the level of writing apprehension, the better the writing proficiency would be. Thus, null hypothesis was rejected.

\section{Research Question 4: What are the students' views regarding their writing apprehension level?}

From the statistical analysis, majority of the students fell under the average writing apprehension (AA) level score and only a handful fell under the high apprehension (HA) and low apprehension (LA) level. However, for this study only 9 respondents were selected (only 3 from each category) to write about their opinions. The following comments illustrated their views:

\section{Question 1: Do you avoid writing? YES / NO? Please explain your answers further.}

HA1: Yes, I always try to avoid writing especially in English class. I always feel difficult to write in English essay.

HA2: Yes, because I don't know how to start the writing and I'm blank of ideas.

HA3: Yes, because it hard for me to come up with idea.

LA1: No, not really. I have never tried to avoid writing. In fact, I really enjoy writing in English all the times. Through writing I'm able to express myself freely.

LA2: No, because I love writing. Through writing I can express my knowledge or opinion regarding the questions 
asked.

LA3: No. I enjoy writing as I made it as my daily routine. Usually I will write an entry for my journal or my diary twice a day to express my feelings and thoughts.

AA1: I'm not really sure to avoid, I write whenever it is necessary only because in English class, I must write in English language. But writing in Bahasa Melayu is my first choice.

AA2: No, but sometimes I don't like the title. So, I just do it for sack of the teacher's request. When I have a lot of ideas, I'll try to do the best I can do.

AA3: No. As I'm writing, I can improve my language, grammar and vocabulary. Although, most of my writing always did too much mistakes, but that's the way I can learn from the past. With writing also, I can improve my conversation with the other people.

Question 2: Are you good at writing? YES / NO? Please explain your answers further.

HA1: NO! I for sure not good in writing. Many English essay and summary can't score high value (markah tertinggi).

HA2: No because my grammar is weak. So, of I'm write something, maybe there is a lot of grammatical error.

HA3: No, because I will make many grammatical error.

LA1: Yes, I believe that I'm quite good at writing. This is because, many of my essays have been published in my previous school magazines and some did win in school level competitions.

LA2: Yes but not always due to grammatical carelessness and others.

LA3: Yes. I am good at expressing my ideas, but I think that I'm not that good on my grammar. I also like to write poems and lyrics apart from writing stories. However, most of the time I like to spend on free writing.

AA1: For English essay, I sometimes write good summary, but essay is hard to write fluently. But, I think I can write well because only essay is hard. I can still score in summary.

AA2: No. But I am improving. The teacher asked me to read more for improving my English and I am trying it.

AA3: Not really.I can write too long if I have a long time, but sometimes I write too short within the time given although I've got many ideas to elaborate the essay.

\section{Question 3: Do you have fear of your writing being evaluated? YES / NO? Please explain your answers further.}

HA1: Yes, I agree that I have fear of the writing being evaluated. For English subject (this semester have write essay $n$ summary). I can not write English very good. Always score low mark in essay from secondary school until here. Low mark for English make my parent not satisfy.

HA2: Yes because I'm afraid if I got lower marks.

HA3: Yes, because I am afraid other people cannot understand the things that I write.

LA1: Since my primary schooling years in Kuala Lumpur, I had the best teachers to teach English language subject. They have encouraged me to write essays to be evaluated by them. So, I have got used to send my essays for evaluations. I welcomed their feedback of my essays because I knew that I will get better in writing essays.

LA2: No, because I'm always confident with my writing although some of my points may be ridiculous.

LA3: Yes, I am worried that other people may not be able to agree with my opinions and thoughts, so I like to keep what I wrote to myself.

AA1: My performance in writing in English is not consistent. Sometimes, I feel that when the lecturer gives back the essay with a smile, he is actually teasing my work.

AA2: Yes. Because after I finish my essay, I will think about the marks that will be given by teacher. In addition, my grammar is not so good as others.

AA3: No. This is because when my writing being evaluated, I can know the mistakes that I did. From that, I can learn and will not repeat it again for the next time. Moreover, the other students also will learn from my writing.

\section{Question 4: Are you nervous about writing? YES / NO? Please explain your answers further.}

HA1: My hand cannot move easily when writing essay. Most of the times, I feel that I must go out of the tutorial to breath fresh air when the lecturer ask me to write an essay and pass-up before the class finishes.

HA2: Yes if the writing have a limit of time. 
HA3: Yes, because I will take a long time to write an essay.

LA1: I seldom feel nervous about writing. Usually I feel nervous during competitions or major exams but if it is in the classroom, I am confident.

LA2: No, there is no such thing as nervous in writing for me.

LA3: No, because I felt free whenever I want to write something. Writing keeps me happy at all times.

AA1: Yes of course I feel nervous sometimes. My writing is not really good compared to my best friend. She is a good writer, so I have to take a look at her writing first to reduce my nervous.

AA2: No. it just me and the paper. Then, examiner will read my essay but he or she do not know who I am. When I lack of time, yes, I'm nervous because my essay not complete yet.

AA3: No. I'm not nervous about writing because it is a commonly task for a student. But, it just nervous when there are less time to finish the writing, but I still got many ideas to elaborate and I will panic.

Question 5: Do you feel expressing ideas through writing is a waste of time? YES / NO? Please explain your answers further.

HA1: Yes, writing is a waste of time for me. I like to do mathematics more than waste time to do writing.

HA2: No, for the person that can writing an essay because by writing, many things can be explain, and express, but, for me is a waste of time.

HA3: Yes, because sometimes through my experience, I cannot express my ideas 100\% compared when I speak.

LA1: Not really, expressing ideas through writing is not a waste of time. However, I feel that, we should change the habit of writing on paper to using blogs.

LA2: No because some persons are afraid in confronting the crowd so it is better to express ideas in writing so that they can avoid themselves from being intimidated by the crowd.

LA3: No. through writing, it makes my mind more creative in thinking. Sometimes whenever I came up with a new idea, I immediately write it down in my diary or journal. Who knows that I can share my ideas with other people around me later on.

AA1: It depends on what we are writing. If the topic is more technical than it a waste of time because many don't like to read, but, if it is to express experience than it is not wasting time because many will read.

AA2: No. For me, I have to list all my ideas before I start writing. It makes me easier to manage my essay.

AA3: No. I'm not agree because when we are writing, we actually ask ourselves and our mind to thinking the best ideas to produce the best writing. We should thinking beyond the limit to express our ideas and make it everyone will love our writing

\section{Question 6: Do you feel good to hand in your essays? YES / NO? Please explain your answers further.}

HA1: Off course no. I am not good in writing essay. So, if the lecturer want me to hand in the essay, I will feel bad.

HA2: No, because I cannot write a good essay.

HA3: No, I always not satisfied with what I write. I feel that I not write the essay best as other people.

LA1: It will be a neutral feeling because I'm used to handing in my essays on time.

LA2: Yes, sometimes essay can be a burden, so it will always make me feel good to hand in the essays as it lifts up my burden.

LA3: Yes, but I'm not comfortable when other people evaluate my writing. However, I'm happy to share my ideas and opinions in the form of writing.

AA1: I don't know how to mention the feelings because I don't know what the lecturer will comment later.

AA2: Yes. In that way, I will know my weakness so that I can improve my English and won't repeat the same mistakes.

AA3: Yes. This is because when the lecturers marking essays, so I will know my mistakes in every aspects such as vocabulary, grammar, language and so on. I also can ask the lecturer to give me a guide in making a good essay.

\section{Discussion}

The researcher's initial assumption was that the students were avoiding writing in English language was due to their high levels of writing apprehension. But, the writing apprehension mean score (WA =36.02) which was within the 
score range of 24 to 48 revealed that the sample respondents did not experience a significantly unusual level of writing apprehension. However, Smith (1984), described that, the closer the score to the limits of this range, that is, scores close to 60 and 96 (in the non-adapted Daly Miller Test score), the more apt respondents were to experience feelings or behaviors' characteristic of the next range of scores which is 97 to 130 (in the non-adapted Daly Miller Test score)for low level of writing apprehension and 25 to 59 (in the non-adapted Daly Miller Test score)for high level of writing apprehension.

Meanwhile, for the relationship between level of writing apprehension and self-efficacy beliefs, it was found out that there was an inverse relationship between the level of writing apprehension and the self-efficacy beliefs. This implied that, with high self-efficacy beliefs, the students had lower writing apprehension levels. This finding was also in line with Trylong (1987) who maintained that there is a negative relationship between students' anxiety levels and their self ratings of language proficiency. In addition, the findings of this study also supported the conclusions of Daly \& Wilson (1983), Onwuegbuzie (1999), and Pajares \& Johnson (1993), these researchers mentioned that writing apprehension level is indirectly correlated with various self-esteem measures, including writing apprehension and self-efficacy beliefs.

In this study, the researcher found a significant relationship between these two variables. Although, the researcher suspected that lower writing apprehension level will lead to better writing proficiency, the analysis of the results yielded the opposite.

For the relationship between writing apprehension level and writing proficiency, the results showed that the higher the writing apprehension level, the better the students proficiency. This finding was also supported by Horwitz (1991) and Onwuegbuzie, Bailey \& Daley (2000) studies, where these researchers also found that, the more an individual becomes anxious in writing, the better performance in writing.

It proved that writing apprehension or anxiety does not only lead to negative effects but there exist possibilities that it may lead to positive conditions too. So, through this study, the researcher believed that having some amount of writing apprehension level may lead to better writing proficiency because an individual may realize of the aspects that he need to accomplish in the writing process.

For the student's view regarding their apprehension level, the researcher had classified questions 1 and 2 as stress apprehensive type, questions 3 and 4 as evaluation apprehensive type and finally questions 5 and 6 as product apprehensive type questions.

For questions 1 and 2, the highly apprehensive respondents HA1, HA2 and HA3 have similarities in their views. Their views pattern showed that all of them avoided writing even at the beginning stages. Moreover, they claimed in difficulties to come up with the ideas to write the essay later on. These respondents also mentioned that they were not good in writing because they predicted that their essay could not score high marks and with lots of grammatical mistakes. These findings confirmed the outcomes of (Daly \& Miller, 1975b) research on the effects on writing performance. The authors found that, high apprehensive writers approached writing with negative attitudes and avoid writing whenever there was an opportunity. In a study related with Malaysian context done by Nur Shidrah et.al (2006) concluded that, students with low proficiency tend to be more apprehensive due to lack of exposures to vocabulary and language skills. The researchers opined that it was expected because in Malaysia English is not the official language of the country.

The LA1, LA2 and LA3 mentioned confidently not to avoid writing. All of them mentioned the purpose of them to participate in writing such as to express themselves and their thoughts. These respondents too claimed that they were good in writing essays for different purposes and audiences. Meanwhile all the AA1, AA2 and AA3 stated their uncertainties in avoiding but were willing to write. With the encouragement and extra time, these respondents mentioned that they too can write.

For questions 3 and 4 which dealt with evaluation apprehensiveness, all HA1, HA2 and HA3 stated the fear of evaluation due to the expected low marks after writing tasks. These respondents too mentioned their nervousness to write within the time limit. However, only HA1 stated the difficulty to breathe when nervous.

LA1 and LA2 stated that, they were not afraid of evaluation, but LA3 was worried about it. However, this did not stop LA3 from writing for own purpose. There was a mixed response for the AA's too. AA1 and AA2 mentioned the fear but AA3 stated the opposite in order not to repeat the same mistakes. For the nervousness level, all LA's stated that they were not nervous while all the AA's mentioned feeling of nervous appeared in certain situations such as lack of time to complete the tasks.

To explain this result, the researcher traced the study of Faigley, Daly, and Witte (1981). This study revealed that, most students with high writing apprehension produced a lower quality work. The authors argued that anxiety level 
rises with the stricter levels of writing evaluation. The researcher also would like to relate the findings with the assessment of the English language subject in this pre-university college, where all compositions are required to be handed in and graded with comments by the lecturers. Furthermore, Zemelman \& Daniels (1988), stressed that students will be interested to write if their audience is clear and their ideas are respected in the classroom.

Lastly, for the product apprehension questions 5 and 6, all the HA's reported that, expressing the ideas through writing is a waste of time do not feel that good to hand in their essays. This finding was in line with (Daly \& Miller, 1975a) whereby high-apprehensive writers seldom participate in writing. In addition, Bloom (1980) too mentioned that high-apprehensive writers were more inclined to procrastinate. Further studies by Smith (1984) too revealed that high apprehensive writers preferred to take lesser chances in their writing. On the other hand, all the LA's and AA's were in the same opinion, whereby they stated that, expressing ideas through writing was not a waste of time. Furthermore, all of the LA's and AA are viewed of good and neutral feelings of handing-in their essays.

The possible explanation for these respondents may be based on the research by Charney, Davida, Newman \& Palmquist (1995). Through different learning styles and attitudes on how the students viewed writing, the study revealed that, students who are active learners are more likely to view writing as something that could be developed. On the other hand, passive learners tend to perceive writing as something that a person is either good or poor.

Furthermore, in a study by Popovich \& Masse (2003) too revealed that pessimistic students were less likely to be successful in writing assignments. While, the optimistic students who thought of having low levels of writing apprehension produced better quality work. So, the researcher believed that these beliefs, have an influence on the on the difference of writing apprehension level among AA's, LA's and HA's among pre-university students.

There are several practical recommendations which could be applied to overcome writing apprehension for these particular students particularly and Malaysian ESL students in general.

First is to provide the students more opportunities for exposure in English language. Murphy (2004), found that lack of exposure to vocabulary and language use contribute to writing apprehension among minority students in United States. Hence, teacher centered approach which is common in Malaysian ESL setting should be changed to student centered such as problem-based approaches. This approach promotes self-accessed learning which will expose the students to vocabulary in an authentic manner which will enrich them to master the language.

Another way to reduce writing apprehension levels is to teach writing as a process rather than products or teaching writing as an art. McDonald (2000) believed that, when writing is being taught as an art, it will provide practical knowledge and some strategies as a guide for the students.

Other than that, the amount writing activities also plays an important part to reduce the writing apprehension level among ESL learners. There is evidence that if the students take more practices in writing activities, the better written essays would be produced. Bromley (2007) argued that, if students are given plenty of opportunities to write and do self-assessment at all levels by their teachers as standard classroom practices, it would be a critical aspect to develop high proficient writers.

\section{Conclusion and Recommendation}

Due to time constraints, the study was conducted only in one of northern region's pre-university college. Therefore, the findings cannot be generalized to all the students in other pre-university colleges. Apart from this particular pre-university students' college, other similar studies which focus more on qualitative aspects of writing apprehension and self-efficacy beliefs could be carried out in all pre-university colleges.

Further research could be conducted to investigate on the aspects of attitude, motivation, and perception on why pre-university students are reluctant to write in English language. In addition, future studies could perhaps improve the generalizability by using larger samples from different pre-university students throughout Malaysia. Furthermore, replication of this study with a sample that is heterogeneous on writing apprehension level and writing proficiency is recommended.

\section{References}

Atay, D., \& Kurt, G. (2006). Prospective teachers and L2 writing anxiety. Asian EFL Journal, 8(4), 100-118. Retrieved July 20, 2010, from http://www.asian-efl- journal.com/Dec 06da\&gk.php

Azlina Bt. Hj. Arshad. (2006). Malay students' use of and attitudes towards spoken English. School of Education. University Sains Malaysia.

Baker, C. (1992). Attitudes and language. Cleavedon: Multilingual Matters Limited.

Baker, C. (1992). Behavior, apprehension, and writing. College Student Journal, 36, 532-543. 
Bloom, L. Z. (1980). The composing processes of anxious and non-anxious writers. A naturalistic study. Paper presented at the annual meeting of the Conference on College Composition and Communication, Washington, D.C., 13-15 march 1980. (ERIC Document Reproduction Service No. ED 185 559).

Bromley, K. (2007). Best practices in teaching writing. In L. Gambrell, L. M. Morrow, \& M. Pressley (Eds.), Best practices in literacy instruction (3rd ed. pp. 243-263). New York: Guildford.

Cates, W. M. (1990). Panduan amali untuk penyelidikan. Kuala Lumpur: Dewan Bahasa \& Pustaka.

Charney, Davida, John H. Newman, \& Mike Palmquist. (1995). "I'm Just No Good at Writing." Written Communication, 12(3), 1995, 298-329. http://dx.doi.org/10.1177/0741088395012003004

Cheng, Y.-S. (2002). Factors associated with foreign language writing anxiety. Foreign Language Annals, 35, 647-656. http://dx.doi.org/10.1111/j.1944-9720.2002.tb01903.x

Cheng, Y.-S. (2004). A measure of second language writing anxiety: Scale development and preliminary validation. Journal of Second Language Writing, 13(4), 313-335. http://dx.doi.org/10.1016/j.jslw.2004.07.001

Daly, J. A., \& Miller, M. D. (1975a). The empirical development of an instrument to measure writing apprehension. Research in the teaching of English, 9, 242-249. Retrieved from http://en.wikipedia.org/wiki/Writing

Daly, J. A., \& Wilson, D. A. (1983). Writing apprehension, self-esteem, and personality. Research in the Teaching of English, 17, 327-341.

Daly, J., \& Miller, M. (1975b). Further studies in writing apprehension: SAT scores, success, expectation willingness to take advanced courses and sex differences. Research in the Teaching of English, 9, 249-253.

Deane, P. (2011). Writing assessment and cognition. Research Report ETS RR-11-14. Retrieved from http://www.ets.org/Media/Research/pdf/RR-11-14.pdf

Faigley, L., Daly, J. A., \& Witte, S. P. (1981). The effects of writing apprehension on writing performance competence. Journal of Educational Research, 75, 16-21.

Gay, L. R., Mills, E. G., \& Airasian, P. (2009). Educational research: Competencies for analysis and application (9th Edition). Pearson International Edition.

Graham, S., Schwartz, S., \& MacArthur, C. (1993). Learning disabled and normally achieving students' knowledge of writing and the composing process, attitude toward writing, and self-efficacy. Journal of Learning Disabilities, 26, 237-249. http://dx.doi.org/10.1177/002221949302600404

Gungle, B. W., \& Taylor, V. (1989). Writing apprehension and second language writers. In D. M. Johnson, \& D. H. Roen (Eds.), Richness in writing: Empowering ESL students. New York: Longman, Inc. pp. 235-248.

Hadley, A. O. (1993). Teaching language in context. Boston: Heinle \& Heinle.

Hanna, K. J. (2010). Student perceptions of teacher comments: Relationships between specific aspects of teacher comments and writing apprehension. Ph.D Dissertation, The University ofNorth Dakota.

Hassan, B. A. (2001). The relationship of writing apprehension and self-esteem to the writing quality and quantity of EFL university students. Retrieved February 19, 2004 from ERIC Database \#ED459671

Horwitz, E. K. (1991). Preliminary evidence for reliability and validity of a foreign-language scale. In F. K. Horwitz, \& D. J. Young (Eds.), Language anxiety: From theory and research to classroom implications (pp. 37-39). Englwood Cliffs, NJ: Prentice Hall.

Krejcie, V. R., \& Morgan W. D. (1970). Determining sample size for research activities. Educational and Psychological Measurement, $\quad 30, \quad 607-610 . \quad$ Retrieved from http://members.multimania.co.uk/renatonunes/tabela\%20tamanho\%20amostra.pdf

Lee, S., \& Krashen, S. (2002). Predictors of success in writing English as a foreign language: Reading, revision.

MacIntyre, P. D. (1995). How does anxiety affect second language learning? A reply to Sparks and Ganschow. Modern Language Journal, 79(1), 90-99. http://dx.doi.org/10.1111/j.1540-4781.1995.tb05418.x

Magno, C. (2008). Reading Strategy, Amount of Writing, Metacognition, Metamemory, and Apprehension as Predictors of English Written Proficiency. Professional Teaching Articles, 29. Retrieved from http://www.asian-efl-journal.com/PTA/pta_July_08_cm.php

McDonald, J. (2000). The Allyn and Bacon sourcebook for college writing teachers. Boston:Allyn and Bacon.

Muhammad Abdel Latif. (2007). The factors accounting for the Egyptian EFL University students' negative writing affect. Essex Graduate Student Papers in Language \& Linguistics, 9, 57-82. 
Murphy, J. C. (2004). Urban children and reading mastery: An examination of the language vocabulary acquisition approach to teaching reading. Reading Improvement, Spring, 41(1), 13-18.

Nor Shidrah Mat Daud., Noor Lide Abu Kassim., \& Nuraihan Mat Daud. (2006). Second language writing anxiety: Cause or effect? Retrieved September $15, \quad 2010$ from http://www.melta.org.my/Doc/second_lang_writing_anxiety.pdf

Noraina Ishak. (2005). Improving students' writing ability in using transition signal through language games. Paper presented at the Seminar Penyelidikan Pendidikan Program Matrikulasi KPM, 2005.

Onwuegbuzie, A. J. (1999). Writing apprehension among graduate students: Its relationship to self-perceptions. Psychological Reports, 84(3), 1034-1039.

Onwuegbuzie, A. J., Bailey, P., \& Daley, C. E. (2000). Cognitive, affective, personality, and demographic predictors of foreign-language achievement. The Journal of Educational Research, 94, 3-15.

Pajares, F., \& Valiante, G. (1999). Grade level and gender differences in the writing selfbeliefs of middle school students. Contemporary Educational Psychology, 24, 390-405. http://dx.doi.org/10.1006/ceps.1998.0995

Pajares, M. F., \& Johnson, M. J. (1993). Confidence and competence in writing: The role of self- efficacy, outcome expectancy, and apprehension. Paper presented at the Meeting of the American Educational Research Association, Altanta, GA, April 12-16, 1993.

Popovich, M. N., \& Mark, H. M. (2003). Individual assessment of media writing student attitudes: Recasting the mass communication writing apprehension measure. Journalism \& Mass Communication Quarterly, 82(2), 339-355.

Rankin-Brown, M. S. (2006). Addressing writing apprehension in adult English language learners. Proceedings of CATESOL State Conference.

Shaharizam, Ismail, Syahfarin Syah, \& Rizal. (2005). The perceptions of using genres of writing for report writing exercise among H5P4 students in Negeri Sembilan Matriculation College. Paper presented at the Seminar Penyelidikan Pendidikan Program Matrikulasi KPM, 2005.

Shell, D. F., Murphy, C. C., \& Bruning, R. H. (1989). Self-efficacy and outcome expectancy mechanisms in reading and writing achievement. Journal of Educational Psychology, 81, 91-100. http://dx.doi.org/10.1037/0022-0663.81.1.91

Smith, M. W. (1984). Reducing writing apprehension. Urbana, IL: NCTE.

Trylong, V. L. (1987). Aptitude, attitudes and anxiety (Unpublished doctoral dissertation). Purdue University, Indiana.

Zemelman, S., \& Daniels, H. (1988). A community of writers: Teaching writing in the junior and senior high school. Portsmouth, NH: Heinemann. 